\title{
Transformation of Retailing in Bangladesh: A Holistic Approach
}

\author{
Md. Jahangir Alam \\ Assistant Professor, Department of Business Administration, Leading University, \\ Ragibnagar, Sylhet-3112, \\ Bangladesh
}

\begin{abstract}
Retailing in Bangladesh is changing rapidly in line with the other countries of the world. The study aims to identify the nature of changes in retailing in Bangladesh along with the practicing theory of retail changes and waves of retail development by reviewing the articles and contents, secondary information from the different sources. Tabular forms of data presentation is used, trend analysis andsubjective judgements are deployed in analyzing the data to reach the decisions. The changing nature of retailing in Bangladesh has the three dimensions-the rapid rise of supermarkets in the urban and semi urban areas, accelerations of the e-commerce \& e-tailing and a start of multichannel retailing. The practicing pattern of retailing in Bangladesh adopts the combined theory of retail changes and belongs to the fourth wave of retail development. The study may help innovating new retail model as well as gives insight to the retail institutions, professionals and policy makers to formulate the proper policy for effective growth and management of the sector.
\end{abstract}

Keywords: Retail Theory, Retail Waves, Supermarket, E-commerce, Multichannel Retailing

DOI: $10.7176 / \mathrm{JMCR} / 64-05$

Publication date: January $31^{\text {st }} 2020$

Introduction: Retailing has been undergoing tremendous changes in developed as well as in developing countries (Humphrey, 2007; Reardon \& Gulati, 2008; Tschirley et. al., 2010; Nsimbi et. al. 2015). The changes in retailing have been the academic concern for the many years, the researchers and scholars explain the numerous theories of the retail changes like the Wheel of Retailing (McNair, 1958), the Retail Accordion theory (Hollander, 1966), The Retail Life Cycle Theory (Davidson, Bates and Bass, 1976), Dialectic theory (Gist, 1968), the Environmental Theory (Blizzard, 1976; Brown, 1987; Gist, 1968; Oren, 1989), the Combined Theory (Kim, $2006)$ etc. where they address the multiple nature of the retail changes. In the last 20 years, retail expansion has accelerated and included more and more countries in South America and East and Southeast Asia as well as a few countries in Africa. Lately, also South Asia and low-income countries in other world regions have become targets for the expansion of retailing chains (Altenburg et al (2016) and this transformation process of retail has been distinguished in four waves that have encompassed different regions and countries (Reardon et al 2003; Monteiro, Farina and Nunes 2012; Dakora, 2012).

Retailing is a traditional business in Bangladesh and like other developing countries of the world, the retail sector in Bangladesh is dominated by small grocery shops in rural areas, and small grocery shops in shop-lots and corner stores in neighborhoods in semi-urban and urban areas (Ali and Faroque, 2017) but the retailing industry in Bangladesh has been observing remarkable changes over the last decade (Siddiqui, Ahmed and Hasan, 2006; Arif, 2013, Shamser, 2014; Ahmed, 2017; Sarker and Ashrafi, 2018). This changes has been addressed in different dimension including the rise of the supermarkets (Shamsher, 2017; Datta, 2017;Sarker and Ashrafi, 2018; Farid et al, 2017), the rapid adoption of e-commerce and e-tailing (Islam and Eva, 2019; Karim and Qi, 2018; Sahel, Anwar and Nandi, 2018; Islam, 2018) and the multichannel retailing (The Daily Star, 2017; futurestartup.com, 2017). There have an immense significance of the retail sector to the economy of the country, it contributes taka 2798225 million in 2017-2018 in current market price and 8.7 million people are employed in this sector which is almost $14.3 \%$ of the total workforce of the country (BBS. 2018). Thus, retail is an important business sector in Bangladesh and this is the high time to be concern about the changes in the industry to keep pace with the global scenario.

Statement of the problem: The super market and mall culture is booming in Bangladesh especially in urban area of the country (Arif, 2013, Shamser, 2014; Ahmed, 2017; Sarker and Ashrafi, 2018), the scholars and researchers got a research momentum in this issue. For example, retail spatial development has been studied in the literatures (Hossain, 2014; Hossain, 1999; 2009), the development of superstore also explained other literatures (Farid et al, 2017; Rahman et al, 2017; Arif, 2013; Datta, 2017; Shahid, 2017), the online marketing and ecommerce activities in Bangladesh is rapidly developing online market (Rahman, 2015; Robenhagen, Shahrukh, \&Taufiq, 2014) though developed countries have matured. Consumer willingness to try online services (Al Noor \&Arif, 2011), strategic government initiative of 'Digital Bangladesh by 2021' (a2i, 2009), local and foreign investment from the private sectors (Garza, 2015; World Bank, 2014) and the growth of the ICT sector (Bank, 2015; KPMG, 2012; Nyenrode, 2014; Robenhagen, Shahrukh, \&Taufiq, 2014) are fueling the rapid growth of e-business and e-commerce in Bangladesh. Most of these literatures discussed the changes of 
retailing in Bangladesh in different perspective and these literatures did not have sufficient empirical or evidence on the changing nature of retailing in the country. Thus it is very important to know the actual changing pattern of retailing in Bangladesh.

Nature, Objectives and Methodology of the Study: The present study is descriptive in nature. The study aims to identify the nature of changes of retailing in Bangladesh. In line with this, the study also discuss the theories of retail changes and the waves of retail development to find out the retail change theory and waves of retail development are related to Bangladesh perspectives. To achieve the objectives, the study reviewed the articles and contents related to retailing in home and abroad, collected secondary information from the different sources like Bangladesh Bureau of Statistics, Bangladesh Supermarket Owners Association, analyzes the publications of Bangladesh Brand Forum etc. Data are presented in different tables and trend analysis as well as subjective judgments used in analyzing the datain reaching the decisions.

Retail Transformation: Theoretical Aspects: Retail change theories identified according to their approach and the well-known theories of retail evolution are (a) Cyclical theory, (b) Conflict theory, and (c) Environmental theory and (d) Combined theory (Clough, 2002; Kim 2003). All these theories of retail changes are explained briefly in the following parts.

- Cyclical Theories: The concept of cyclical theories interprets that retail institutions evolve in a rhythmical pattern or cycle by adjusting their earlier patterns, include the Wheel of Retailing, the Retail Accordion, the Polarization Principle, the Multi-Polarization Model and the Retail Life Cycle. Wheel of retailing theory(McNair, 1958),states that the evolution process consists of three phases: entry phase-starts with the opening of innovative retail institutions, which initially offer limited products with low prices and minimum services, then shifts to the trade-up phase characterizing elaborate facilities, expected essential and exotic services, higher rent locations fashion orientations higher prices extended product offering and ends with vulnerable phase featuring higher levels of operational practices, operation costs increase, product prices rise, and profit margins tend to erode, lose market share and profitability and emergence of a new innovative retailer in the next cycle. The retail Accordion Theory (Hollander, 1966), demonstrate retail evolution as a cyclical trend starting with broad assortment of merchandise, alternates with domination by specialized, narrow-line merchants and returns to the inventory profile of the old operation with a broad assortment of many lines of merchandise. The number of product lines and the depth of inventory inflates over time which Hollander analyzed in the general stores, drug stores, supermarkets, department stores, and discount stores in the United States. The Polarization Principle (Kirby, 1976a, 1976b) argued that the consumer prefer small stores conveniently located close to the residence and use these stores for augment shopping for emergencies or purchase of perishables and fresh food items instead of shopping from the larger, fewer, and less spatially concentrated supermarkets. The Multi Polarization Principle(Brown, 1987), argued that retailing evolves with three dimensions simultaneously including specialization, smaller outlets and a high level of service which are driven by inventory diversification instead of single polarization either low-margin/high-turnover outlets or high margin/low-turnover retailing. The Retail Life Cycle Theory (Davidson, Bates and Bass, 1976), explains the retail institutions goes natural evolutionary process like the products life cycle (Davidson, 1970; McCammon, 1975) and the stages of the life cycle are innovation, accelerated development, maturity and decline argues that adopting changes in these lifecycle stages is the way to maintain profit.

○ The Conflict Theory: Conflict theories, named as Dialectic retail evolution lights on the interinstitutional contention arising when a new retail institution appears and the theory was proposed by Gist (1968). In Dialectic theory, a current retail institution is confronted by its competitor because of competitive advantages and current retail institution imitates the features of competitor to elevate its existing characteristics results a new retail institution. Thus while two retail institutions are in conflict, a new retail institution is innovated with better features than the existing two retail institutions. When a new retail institution arrived, existing retailer resists but with the time passes, it started adopting the features of new one and differentiating it by forming a new retail institution (Brown, 1987; 1988).

- Environmental Theory: The common concept among the Environmental theorists is that the retail environment is the main factor to retail changes, and to persist change and competition, retail institutions must evolve by adapting or adjusting to the environmental changes (Blizzard, 1976; Brown, 1987; Gist, 1968; Oren, 1989). The major environmental elements causing retail evolution are the demographic, social, economic, cultural, technological legal environment and competition (Gist, 1968; Brown, 1988; Oren, 1989). The concept suggests that the retail institution can survive only when it best adapts to environmental changes (Brown, 1987).

- Combined Theory: Combined theory attempts to combine two or more evolution theories to explain retail evolution. The combined theories includes the Combination of Cyclical and Environmental Theory, Combination of Cyclical and Conflict Theory, Combination of Environmental and Conflict theory, Combination of Environmental, Cyclical and Conflict Theory andCombined Retail Evolution Model. Combination of Cyclical and Environmental Theory addressed that a retail institution's cyclical evolution followed simultaneously to environmental changes believing the Wheel of Retailing theory (i.e., Cyclical theory) and environmental changes 
(e.g., cultural, political, socio-economic, legislative, and business structure changes) are the main factors on cyclical evolution of a retail institution type (i.e., Environmental theory) (Brown, 1987). Combination of Cyclical and Conflict Theory proposed that a retail institution evolved cyclically, while conflicting with a new innovative retailer or other challengers (Dreesman, 1968; Bartels, 1981;Brown, 1988), institutional conflicts forced retail institutions' trade-up practices; therefore, retail institutions change or evolve to compete with their competitors. Similarly in the Three Wheels of Retailing theory (Izraeli, 1973) proposed the three wheels of retail changes are low-end innovation, high-end innovation, and high and low-end conventional retailers which evolves cyclically but in time of changes conflicts with high-end conventional retail institution types and highend innovations of a retail institution type, and low-end conventional retail institution types conflict with lowend innovations. As a result, two new high-end and low-end innovators in retail institution types occurred. Combination of Environmental and Conflict theory noted that environments were evolving with changes in the economy, technology, society, consumer demographics, marketing, and managerial methods and a new retail institution type is evolving under the environmental developments, additional retailers start competing with this retail institution type. As a result of the conflict, another new retail innovation is created (Guiltinan, 1974; Alderson, 1957; Brown, 1988). Jeffreys (1954) and Regan (1964) also explained retail evolution with environmental changes (e.g., an increasing living standard) and inter-institutional conflicts. Combination of Environmental, Cyclical and Conflict Theory proposed a combination of all three retail evolution theories to explain evolutions of retail institution types (Hall, Knapp \&Winsten, 1961; Kaynak, 1979; Shaw, 1978)focusing on food and clothing industries with statistical analysis providing insight into changes in gross margin (i.e., Cyclical theory), number of stores within a region (i.e., Conflict theory), and environmental variables (i.e., Environmental theory).Combined Retail Evolution Model synthesize the previous retail evolution theories and consumer patronage theories into a better model to fit all types of retail evolution theories a new theory named Combined Retail Evolution model (CREM) is proposed (Kim, 2006). The CREM shows retail institution types in a change process of three principles: (a) rhythmical patterns of spiral change, (b) the effects of conflict or challenge from competition, and (c) the influence of retail environments.

Thus from the above discussion it portraits that the cyclical theories are focusing on the rhythmic pattern of retail evolution, conflict theory addresses the confrontation of new retail to existing retail develops a new retail, the environmental theory reveals that the changes in the environmental forces causes the retail change and the combined theory enumerates the two or more retail evolution theory jointly fuels the retail changes.

Retail Development Waves: The transformation process of retail has been distinguished in four waves that have encompassed different regions and countries (Reardon et al 2003; Monteiro, Farina and Nunes 2012; Dakora, 2012). The first wave took place in the early 1990s and included countries from South America (Argentina and Brazil), East Asia (the Philippines, the Republic of Korea, Taiwan and Thailand), Central Europe (Czech Republic) and South Africa. The second wave started in the mid-1990s, included parts of Southeast Asia (Indonesia), Latin America (Colombia and Guatemala) and South-Central Europe (Bulgaria) as well as Mexico. The third wave occurred in the early to mid-2000s and involved the spread of supermarkets to other parts of Central and South America (Bolivia, Nicaragua and Peru) and Southeast Asia (Vietnam), and to certain areas of China, India and Russia. A few supermarkets were even introduced at this time in a number of African countries (Kenya, Zambia and Zimbabwe), but the penetration of supermarkets in these countries remains fairly low. The fourth wave mainly comprises African countries (Angola, Mozambique, Tanzania and Uganda) that received South African FDI in the mid-2000s but have not yet substantially restructured their traditional retail sectors and in poorer countries in South Asia (outside India) including Bangladesh (Bachmann, 2008; Wrigley and Lowe, 2010; Dakora, 2012; Reardon, 2008; Reardon and Gulati 2008). However, the characteristics of the retail development waves are explained in the following table. 
Table-1: Characteristics of the waves of retail development

\begin{tabular}{|c|c|c|c|c|c|}
\hline Period & Countries/regions & Product categories & $\begin{array}{l}\text { Socio- } \\
\text { economic } \\
\text { strata }\end{array}$ & $\begin{array}{l}\text { Location of } \\
\text { the Countries }\end{array}$ & $\begin{array}{l}\text { Growth in } \\
\text { supermarkets' } \\
\text { average share in } \\
\text { retail sales }\end{array}$ \\
\hline $\begin{array}{l}\text { First } \\
\text { wave } \\
\text { started in } \\
\text { early } \\
1990 \text { s }\end{array}$ & $\begin{array}{l}\text { Much of South } \\
\text { America, East Asia } \\
\text { (outside China), and } \\
\text { South Africa }\end{array}$ & \begin{tabular}{lr}
\multicolumn{2}{l}{ Supermarkets } \\
operate initially \\
with \\
products
\end{tabular} & High incomes & Large cities & $\begin{array}{l}\text { From } 10 \text { percent } \\
\text { around } 1990 \text { to } \\
\text { about } 50-60 \\
\text { percent by the } \\
\text { mid- } 2000 \text { s }\end{array}$ \\
\hline $\begin{array}{l}\text { Second } \\
\text { wave } \\
\text { started in } \\
\text { mid- to } \\
\text { late } \\
\text { 1990s }\end{array}$ & $\begin{array}{l}\text { Mexico, Central } \\
\text { America, and much of } \\
\text { Southeast Asia }\end{array}$ & $\begin{array}{l}\text { Semi processed } \\
\text { Foods (for example, } \\
\text { dairy products) and } \\
\text { foods that require } \\
\text { minimal processing } \\
\text { and packaging (for } \\
\text { example, chicken, } \\
\text { pork). }\end{array}$ & Middle class & $\begin{array}{l}\text { Intermediate } \\
\text { cities }\end{array}$ & $\begin{array}{l}\text { From } 5-10 \\
\text { percent in } 1990 \\
\text { to } 30-50 \text { percent } \\
\text { by the mid-2000s }\end{array}$ \\
\hline $\begin{array}{l}\text { Third } \\
\text { wave } \\
\text { started in } \\
\text { late } \\
\text { 1990s } \\
\text { and early } \\
\text { 2000's }\end{array}$ & $\begin{array}{l}\text { China, India and } \\
\text { Vietnam }\end{array}$ & $\begin{array}{l}\text { The third wave } \\
\text { includes fruits and } \\
\text { then vegetables. }\end{array}$ & $\begin{array}{l}\text { Lower class } \\
\text { (the urban } \\
\text { poor) }\end{array}$ & $\begin{array}{l}\text { Small towns } \\
\text { in rural areas }\end{array}$ & $\begin{array}{l}\text { Reached about 2- } \\
20 \text { percent by } \\
\text { mid-2000s; } \\
\text { supermarket sales } \\
\text { grew at } 30-50 \\
\text { percent a year }\end{array}$ \\
\hline $\begin{array}{l}\text { Forth } \\
\text { wave } \\
\text { started in } \\
\text { mid- } \\
2000 \text { s }\end{array}$ & $\begin{array}{l}\text { African countries } \\
\text { (Angola, Mozambique, } \\
\text { Tanzania and Uganda) } \\
\text { and poorer countries in } \\
\text { South Asia (outside } \\
\text { India) including } \\
\text { Bangladesh. }\end{array}$ & $\begin{array}{l}\text { Fruits } \\
\text { Vegetables, and } \\
\text { electronics } \\
\text { fashion items }\end{array}$ & $\begin{array}{l}\text { Young, dual } \\
\text { income and } \\
\text { tech-savvy } \\
\text { consumers } \\
\text { with more } \\
\text { disposable } \\
\text { income }\end{array}$ & $\begin{array}{l}\text { Larger and } \\
\text { intermediate } \\
\text { cities }\end{array}$ & $\begin{array}{l}\text { Not specified yet, } \\
\text { still sporadic }\end{array}$ \\
\hline
\end{tabular}

Source: Reardon et al (2003); Reardon et al. (2007); Reardon (2008); Reardon and Gulati (2008); Anku and Ahorbo (2017); Monteiro, Farina and Nunes (2012); Dakora, 2012

The above table depicts the dynamic nature of retail development waves, and explains the differences among the waves. The first wave of retail development focuses on the large cities targeting the high income segments but the fourth wave shifts towards the larger and intermediate cities together targeting the young, dual income and tech savvy consumers.

Nature of Retail Transformation in Bangladesh: The retailing industry in Bangladesh has been observing remarkable changes over the last decade toward organized retailing with the immense development of the large scale retail stores in the country especially in urban area (Siddiqui, Ahmed and Hasan, 2006; Arif, 2013, Shamser, 2014; Ahmed, 2017; Sarker and Ashrafi, 2018). This trends in retail industry is occurring due to some important changes in the business world including growing diversity in retail format, increasing industry competition, globalization, use of multiple channels by the customers (Levy \&Weitz 2005) and economic and trade liberalization, the growth of urbanization, increasing number of women working outside their home, rising per capita income, Government's liberal attitude towards foreign imported products which also changing the retail sector of Bangladesh (Shamsher, Abdullah and Saha, 2012, Faid et al, 2018). Though the retail industry of Bangladesh has been dominating by the traditional retailers', the growth of super market and the growth of Ecommerce have dramatically changes the retail scenario of Bangladesh. In this section, the nature of changes in retailing of Bangladesh is discussed.

i. Pattern of changes on the basis of legal status and ownership status: The changing retail pattern in Bangladesh can be explores through the ownership of the organization and their legal status. The Table- 2 explains the number of establishment by legal status and the Table-3 presents the number of establishments by ownership status. 
Table-3: Number of Establishment by Legal Status

\begin{tabular}{|l|l|l|l|l|l|}
\hline \multirow{2}{*}{ Survey/Census } & \multicolumn{5}{c|}{ Legal Status } \\
\cline { 2 - 7 } & \multicolumn{1}{|c|}{ Total } & \multicolumn{1}{|c|}{ Individual } & Partnership & Private & Others \\
\hline Wholesale and Retail Trade Survey 2002-03 & 1574334 & 1574298 & 23 & 50 & 13 \\
& & $(99.99)$ & $(0.00)$ & $(0.00)$ & $(0.00)$ \\
\hline Wholesale and Retail Trade Survey 2009-10 & 2650123 & 2125482 & 489505 & 32997 & 2139 \\
& & $(80.23)$ & $(18.47)$ & $(1.25)$ & $(0.08)$ \\
\hline
\end{tabular}

Source: BBS, 2013

The above table-3 shows that the total 2650123 establishments in Bangladesh according to the Wholesale and Retail Trade Survey 2009-10 among those individual ownership and legal status holds 2125482 organization, partnership organizations are 489505, private organizations are 32997 and Others are 2139 whereas in the Wholesale and Retail Trade Survey 2002-03 shows that individual ownership and legal status holds 1574298 organization, partnership organizations are only 23 , private organizations are only 50 and others are only 13.

Table-4: Number of Permanent Establishment by Ownership Status

\begin{tabular}{|l|l|l|l|l|l|l|l|l|l|}
\hline $\begin{array}{l}\text { Individual/ } \\
\text { Family }\end{array}$ & Partnership & $\begin{array}{l}\text { Private } \\
\text { Ltd. }\end{array}$ & $\begin{array}{l}\text { Public } \\
\text { Ltd. }\end{array}$ & $\begin{array}{l}\text { Government } \\
\& \\
\text { Autonomous }\end{array}$ & $\begin{array}{l}\text { Foreign } \\
\text { \& Joint } \\
\text { Venture }\end{array}$ & $\begin{array}{l}\text { Co- } \\
\text { operatives }\end{array}$ & NPI Expatriate & Others & Total \\
\hline 2459435 & 18901 & 56358 & 77 & 291 & 71 & 664 & 298 & 290 \\
\hline
\end{tabular}

Source: BBS, 2015

It is observed from the table- 4 that, there are 2540688 establishments exists, among those individual and family business are 2459435, partnership 18901, private Ltd 56358, Public Ltd. 77, Government \& Autonomous are 291, Foreign \& Joint Venture are 71, Co-operatives are 664, others are 4303.

ii. Pattern of changes on the basis of person engaged and average establishment size: Another dimension of retail changes in Bangladesh is identifying the changes on the basis of number of person engaged and by establishment size.

Table: 6: Number of Person Engaged by Establishment Size

\begin{tabular}{|l|c|c|c|c|c|c|c|}
\hline Survey/Census & \multicolumn{7}{|c|}{ Size of Establishment by person } \\
\cline { 3 - 8 } & Total & $<3$ & 3 to 5 & 3 to 4 & 6 to 9 & 5 to 9 & $\begin{array}{c}10 \& \\
\text { Above }\end{array}$ \\
\hline Economic Census-2001-03 & 3852874 & 1893316 & & 1211159 & & 593196 & 155203 \\
\hline $\begin{array}{l}\text { Wholesale and Retail Trade } \\
\text { Survey-2002-03 }\end{array}$ & 2126177 & 1753816 & 288648 & - & 33935 & - & 49778 \\
\hline $\begin{array}{l}\text { Wholesale and Retail Trade } \\
\text { Survey-2009-10 }\end{array}$ & 5264900 & 3069673 & 1566552 & - & 384695 & - & 243980 \\
\hline
\end{tabular}

Source: BBS, 2013

The above table- 6 shows that retail organizations are changing rapidly, in the Wholesale and Retail Trade Survey-2002-03 there were only 33935 organization deployed 6 to 9 people which increased to 384695 in Wholesale and Retail Trade Survey-2009-10 and there were only 49778 organizations deployed 10 \& above persons in Wholesale and Retail Trade Survey-2002-03 which reached to 243980 organizations in Wholesale and Retail Trade Survey-2009-10. Thus the table indicates that, the retailing business is changing, more people are deployed as the business is expanding into large scale business.

iii. Pattern of changes on the basis of fixed asset: The pattern of retail changes in Bangladesh also observed on the on the basis of fixed assets deployed in the retail business. If the fixed assets are increased, it will indicate that the nature of investment in retail business is changing and thereby the largescale retailing is increasing. The following table shows the number of organizations as per the fixed assets.

Table 7: Establishments Size by Current Fixed Assets (in lac taka)

\begin{tabular}{|l|l|l|l|l|l|l|l|}
\hline Investment & Up to 5 & $5-50$ & $50-100$ & $100-1000$ & $1000-1500$ & $1500-3000$ & $3000+$ \\
\hline $\begin{array}{l}\text { No. of } \\
\text { Establishment }\end{array}$ & 3057653 & 523543 & 6418 & 1342 & 140 & 33 & 23 \\
\hline
\end{tabular}

Source: BBS, 2015

The above table- 7 indicates that there have 23 establishments where the fixed assets belong to taka $3000+$ Lac and 33 organizations have taka 1500-3000 lacs fixed assets. Similarly, there have 140 organizations having taka 1000-1500 lacs, 1342 organizations having taka 100-1000 lacs fixed capital.

iv. The growth of super market sector: Though the researchers explained the, supermarket concept has been diffused in Bangladesh since 1990s (Azad, Hossain and Parveen, 2012), but the sector got a momentum by the inception Ágora' in the year 2001. Before 2000 the retail trade was dominantly controlled by thousands of small retailers in the traditional stores or bazaars with no attention from the business enterprises where shoppers 
solely had to depend on these unorganized markets to buy their essentials (Shamsher and Hossain, 2011). But the old retail landscape is changing rapidly with the increased industrialization, rising per capita income of the middle segment with substantial buying power comparable to many western cities and certainly the economic growth of the country along with the effects of globalization, economic and trade liberalization, the growth of urbanization, increasing number of women working outside their home, rising per capita income, and the Government's liberal attitude towards foreign imported products and other factors drives the growth of better shopping environment in large cities (Ali and Faroque, 2017;Shamsher, Abdullah and Saha, 2012). In the last eighteen years, many small and big superstores have started their retailing business to attract middle and upper middle class consumers, segments which are shifting their shopping preferences to the super stores from the traditional markets. Besides the large superstores like Agora, Shwapno and Meena Bazar, a growing number of medium and small superstores are also flourishing in the major cities like the capital Dhaka, the port city Chittagong(Shamsher and Hossain, 2012) and the patriot and remittance hub Sylhet (Rahman, Islam and Hasan, 2016). The following table presents the total number of supermarkets operating in Bangladesh.

Table-8: Number of Super Market in Bangladesh as on May 30, 2019

\begin{tabular}{|c|c|c|c|c|c|}
\hline $\begin{array}{l}\text { Name of the } \\
\text { Supermarket }\end{array}$ & $\begin{array}{l}\text { Number of } \\
\text { outlet in Dhaka }\end{array}$ & $\begin{array}{l}\text { Number of } \\
\text { Outlet in Sylhet }\end{array}$ & $\begin{array}{l}\text { Number of outlet } \\
\text { in Chattagram }\end{array}$ & $\begin{array}{l}\text { Other } \\
\text { Locations }\end{array}$ & $\begin{array}{l}\text { Total Number } \\
\text { of outlet }\end{array}$ \\
\hline SHWAPNO & 48 & 5 & 3 & 6 & 62 \\
\hline AGORA & 14 & 2 & 1 & 0 & 17 \\
\hline MEENABAZAR & 16 & 0 & 1 & 0 & 17 \\
\hline Others & 62 & 12 & 8 & 30 & 112 \\
\hline Total & 140 & 19 & 13 & 36 & 208 \\
\hline
\end{tabular}

Source: Author by visiting the websites of the supermarkets.

The above table- 8 shows that the total numbers of supermarkets I Bangladesh are 208 among which the superstore Shwapno has the 62 outlets, Agora has the 17 outlets and Meenabazar has the 17 outlets. There have 140 outlets of the supermarkets are in Dhaka, 19 outlets are in Sylhet, 13 in Chittagong and 36 are in the other locations of the country.

If we observe the growth trend of supermarket is presented in the table-9, we see that the total numbers of supermarket in the year 2012 were 113 which increased in the 126 in2013 and in the year 2019 the total number of supermarkets reaches to 208. The table shows that there have positive growths of the supermarket since 2012 to 2019 .

Table 9: Number of Stores

\begin{tabular}{|l|l|l|l|l|l|l|l|l|}
\hline Supershop & $\mathbf{2 0 1 2}$ & $\mathbf{2 0 1 3}$ & $\mathbf{2 0 1 4}$ & $\mathbf{2 0 1 5}$ & $\mathbf{2 0 1 6}$ & $\mathbf{2 0 1 7}$ & $\mathbf{2 0 1 8}$ & $\mathbf{2 0 1 9}$ \\
\hline Shwapno & 40 & 43 & 46 & 47 & 57 & 62 & 62 & 62 \\
\hline Agora & 12 & 14 & 14 & 15 & 13 & 14 & 16 & 17 \\
\hline Meena Bazar & 9 & 12 & 14 & 16 & 16 & 16 & 17 & 17 \\
\hline Others & 52 & 57 & 66 & 74 & 74 & 84 & 101 & 112 \\
\hline Total & 113 & 126 & 140 & 152 & 160 & 176 & 196 & 208 \\
\hline
\end{tabular}

Source: Bangladesh Supermarket Owners Association (BSOA)

If we observe the company wise growth trend, it shows that the largest Supershop chain in Bangladesh is SHWAPNO having 62 outlets which was 40 in 2012, 43 in 2013, 46 in 2014, 47 in 2015, 57 in 2016 and since 2017 it remains in 62 outlets. Similarly there have a positive growth rate in the company named AGORA since 2012 to 2019 except in the year 2016 and the MEENABAZAR also has positive growth rate since 2012 to 2019. The table also indicates that not only these three companies but also other organizations has a positive growth trends since 2012 to 2019 .

The changes of the retail sector can also be assessed through the economic contribution of the sector to the GDP of the country presented in the following table. 
Table 10: Contribution of the sector to the GDP (in million taka)

\begin{tabular}{|l|l|l|l|l|l|l|l|}
\hline \multicolumn{1}{|c|}{ Sector } & \multicolumn{1}{c|}{$\mathbf{2 0 1 2}$} & \multicolumn{1}{c|}{$\mathbf{2 0 1 3}$} & \multicolumn{1}{c|}{$\mathbf{2 0 1 4}$} & \multicolumn{1}{c|}{$\mathbf{2 0 1 5}$} & \multicolumn{1}{c|}{$\mathbf{2 0 1 6}$} & $\mathbf{2 0 1 7}$ & \multicolumn{1}{c|}{$\mathbf{2 0 1 8}$} \\
\hline Wholesale and Retail & $1,545,794$ & $1,725,752$ & $1,925,854$ & $2,142,574$ & $2,439,581$ & $3,212,040$ & $3,212,040$ \\
\hline in \% & $13.54 \%$ & $13.48 \%$ & $13.33 \%$ & 13.01 & 13.05 & 13.15 & 13.31 \\
\hline Supermarket & 14,520 & 12,420 & 15,130 & 17,460 & 17,810 & 18,810 & 19,370 \\
\hline in \% rote of & 1.60 & 1.28 & 1.46 & 1.58 & 1.53 & 1.53 & 1.49 \\
\hline $\begin{array}{l}\text { Growth rate } \\
\text { Superstores }\end{array}$ & -14.5 & 21.82 & 15.41 & 2.04 & 5.57 & 3.00 \\
\hline
\end{tabular}

Source: BBS, $2019 \&$ future startup (2019)

The table shows that in the year 2012, the wholesale and retail sector contributed 1,545,794 million taka to the GDP of the country which was $13.54 \%$ to total GDP. In the next consecutive years the contribution of the sector rises and reaches to the 3,212,040 million taka in the year 2018 which is $13.31 \%$ to the total GDP of the year. The contribution of the supermarket sector in the year 2012 was taka 14,520 million and it was $1.6 \%$ to the GDP which drops to taka 12,420 million in the year 2013 and it was $1.28 \%$ to the GDP but since 2014 to 2018 the contribution of this sector rises consecutively and reaches to taka 19,370 million and it was $1.49 \%$ to the total GDP. The growth rate shows ups and down trends but the total increase in the contribution observed in each year.

v. The Growth of E-commerce and E-tailing: Bangladesh is rapidly developing online market (Islam Md. Shafiqul, 2018;Babar Z. M, 2017;Oishe S. F, 2017;Rahman, 2016; Rahman, 2015; Robenhagen, Shahrukh, \&Taufiq, 2014). Consumer willingness to try online services (Al Noor \&Arif, 2011), strategic government initiative of 'Digital Bangladesh by 2021' (a2i, 2009), local and foreign investment from the private sectors (Garza, 2015; World Bank, 2014) and the growth of the ICT sector (Bank, 2015;KPMG, 2012;Nyenrode, 2014;Robenhagen, Shahrukh, \&Taufiq, 2014) are fueling the rapid growth of e-business and e-commerce in Bangladesh. Though the Internet was launched in Bangladesh in December, 1993 that time only e-mail facility was provided through the internet on that time. In 1996 at June online facilities was ensure by the government via the Fiber Optical networks the inter-cities were connected together. At the very beginning of 2000 , there were sixty thousands internet networks in Bangladesh (Ali, Ahmed and Rahman, 2016). Three types of ECommerce are popular in Bangladesh. They are (i) Business-to-Business (B-2-B), (ii) Business-to-Consumer (B2-C) and Consumer-to-Consumer (C-2-C) (Shahidul, 2010). The E-Commerce Association of Bangladesh (e$\mathrm{CAB}$ ) presented a list of E-commerce sites on their website (e-CAB.net).According to e-Commerce Association of Bangladesh (NewAge, 2018), over 715 businesses are members of e-CAB, which delivered 30,000 products in 2017 and transacted Tk 1,800 crore and currently country's total e-commerce market size is more than Tk 2,000 crore a year and that is growing at 40 to 50 percent annually (The Daily Star, 2018). In addition, there are 1,000 e-commerce-based sites and 10,000 Facebook pages that run online based businesses as 3G internet3-4 years back led to rapid adoption of online shopping. There are 20 lakh regular online customers, among which people between 25 and 34 years shop the most from the local e-commerce sites, a recent study found and the 35-44 and 18-24 age brackets take up the second and third places, according to the study by Kaymu Bangladesh, which is backed by Rocket Internet, saw 400 percent growth in the last one and a half years and now has 10,000 registered sellers and 100,000 different products on its website (Islam, 2018).Though the e-commerce size is still is a mere 0.7 per cent of the country's total retail market (NewAge 2017), the internet subscribers of Bangladesh are 90.5 million (BTRC, 2018) has strengthen the growth of local e-commerce, F-commerce (merchants conducting online business through Facebook pages) and e-grocery startups; other reasons for the surge in orders for e-commerce players is that banks and mobile financial service providers are offering incentives such as cash backs, discounts and gift to bring people to the digital platform (The Daily Star, 2018) and most importantly, the rapid growth of internet-enabled mobile phones, that situation is likely to change fast (Islam, 2015).

vi. Multi-Channel Retailing Scenario in Bangladesh: The multichannel retailing is not seen at large in Bangladesh. But as the e-commerce and the e-tailing is growing in Bangladesh due to as the consumers are getting more and more digitally attuned, which eventually ends up having a profound impact on their consumption pattern, business organizations are taking initiatives for establishing the multichannel retailing in Bangladesh.A report (The Daily Star, 2017) says that the supermarket chains are stepping into the e-commerce bandwagon, to meet the growing demand for convenience in shopping for perishables and other consumer goods. On the April 18, the leading supermarket chain Meena Bazar launched its online platform, meenaclick.com in aiming to operate their business in both online and mena stores also. The senior management of the retail chain SHWAPNO of Bangladesh also thought of becoming Omni channel business as only brick and mortar or only ecommerce is not enough to become successful now a days (futurestartup.com, 2017) and finally, though the trend of online grocery shopping is a relatively new concept in Bangladesh, SHWAPNO launched its ecommerce site along with taking advantage of existing infrastructure aiming to build a hyper local ecommerce operation through providing the integrated retail experience. In an interview, the SHWAPNO personnel said that as they have an existing customer base, brand awareness and infrastructure, it will easy for them to operate their business on the multichannel arena (futurestartup.com, 2018). Another business house in Bangladesh named 
Meghna Group with their FMCG brand 'Fresh' along with the traditional business started their online store efresh store, currently serving in the customers of Dhaka city only.

From the discussion on the nature of retail changes in Bangladesh it can be concluded that the traditional retailing of Bangladesh is shifting towards the organized retailing particularly the largescale retail business including the supermarkets are in rapid rise, the boom of e-commerce and e-tailing is fueling the changes but still it is in the initial stage and multichannel retail here is getting a bit attention.

Retail Change Theories and Retail Development Waves in Bangladesh Perspective: The nature of retail changes in Bangladesh offers a few unique characteristics. The table-3 shows that, as per the Wholesale and Retail Trade Survey 2002-03, the $99.99 \%$ of retail institutions have individual legal status which fall down to $80.23 \%$ in the Wholesale and Retail Trade Survey 2009-10 and Partnership, Private and Other ownership rises. The table-4 also shows the rise of partnership, private limited, public limited, government and autonomous and foreign and joint venture retail organizations in the country. Similarly, the table- 6 explores the size of retail establishment by person engaged and seen that the institutions having employees 10 \& above rises in both Economic census and Wholesale and retail trade survey. This trend shows that the individually owned retail organizations are in vulnerable phase which indicate the Cyclical theory especially the wheel of retailing theory is related with the situation. On the other hand, the table-7 shows that establishment size as per the current fixed assets and there have 23 organization which has assets more than 3000 lacs taka, 33 organizations having 15003000 lacs taka and 1342 organization having 100-1000 lacs taka. This indicate that while reducing the number of individually owned retail institutions, new forms of high investments firms are arising. The table- 8 shows the number of supermarkets in Bangladesh and the table-9 shows the growth trend of supermarkets from 2012 to 2019 and illustrates there have a positive growth in supermarkets in Bangladesh. The principles of conflict theory, especially dialectic theory explains that the current retail institution is confronted by its competitor because of competitive advantages and current retail institution imitates the features of competitor to elevate its existing characteristics and a new form of retail institution arrived. Considering the development of supermarkets in Bangladesh, the existing traditional retailers are shrinking down, and trying to adopt the changes and hence the new corporate retail is arising here which matches the characteristics of conflict theory. The properties of environmental theory illustrates that the new retail form emerged due to the changes in the retail environments like demographic, social, economic, cultural, technological legal environment and retail institutions can survive only when they adopts this environmental changes. The recent development in information technology in Bangladesh (Bank, 2015; KPMG, 2012; Nyenrode, 2014; Robenhagen, Shahrukh, \&Taufiq, 2014), Consumer trend in adopting online services (Al Noor \&Arif, 2011), government initiative of 'Digital Bangladesh by 2021' (a2i, 2009), and local as well as foreign investment (World Bank, 2014) dramatically changes the retail scenario of Bangladesh and a rapid rise in e-commerce, e-tailing along with the multi-channel retailing is observing here which synchronized with the retail environmental theory. The combined retail change theories focuses on the combination of two or more retail evolution theories and from the above discussion on the nature of change in the retailing of Bangladeshit is evident that, in Bangladesh the Combination of Cyclical, Conflict and Environmental theory exists as well as the propositions of Combined Retail Evolution Model i.e. the rhythmical patterns of spiral change, the effects of conflict or challenge from competition, and the influence of retail environments.

In case of retail development waves, many researcher argued that Bangladesh belongs to the forth wave of retail development (Anku and Ahorbo, 2017; Monteiro, Farina and Nunes, 2012; Dakora, 2012; Bachmann, 2008; Wrigley and Lowe, 2010; Reardon and Gulati, 2008). The characteristics of the forth wave explained in the table-1 and the nature of retail changes as well as development in Bangladesh are matches together, for examplethe location of the fourth wave retail institutions are belongs to the larger and intermediate cities and the supermarkets of Bangladesh mostly located in the major and intermediate cities (Ali and Faroque, 2017; Shamsher and Hossain, 2012; Rahman, Islam and Hasan, 2016). The Bangladeshi supermarket is rising due to rising per capita income (Ali and Faroque, 2017), Consumer willingness to try online services (Al Noor \&Arif, 2011) which are similar to the characteristics of the fourth wave retail development.

Managerial Implication of the Study: The present study has several implications. Firstly, the study summarizes multiple theory of retail changes and their characteristics. Several literatures explains the changes in the retail sector of Bangladesh but few of them focuses on the theoretical aspects and the current study identifies that the nature of changes of retailing in Bangladesh belongs to the properties of the combined retail evolution theory. This finding may lead the future researcher to generate further model of retail changes applicable in Bangladesh. Secondly, this study identifies the development of retail sector of Bangladesh belongs to the fourth wave which spread over the larger and intermediate cities targeting the young, dual income family empowering women and tech-savvy consumers with more disposable income offering the fresh fruits and groceries, electronics and fashion products. The retail organizations and professionals may get insight from this and may rethink about the strategic retail decisions like segmentation, merchandising the retail assortments, targeting the customers and even the medium of promotion the business more precisely. Thirdly, the supermarket sector in 
Bangladesh is rapidly rising and contributing significantly to the GDP but there have not proper policy for the sector. The government and policy makers may formulate policy to manage and regulate this sector effectively. Fourthly, the e-commerce and e-tailing is getting momentum in existing retail scenario. The diffusion of ecommerce affects the whole retail environment and future researcher may study the nature and causes of diffusion of e-commerce, impact of e-commerce on the existing retailers etc.

Conclusion: The retailing in Bangladesh is changing rapidly and the nature of changes has the three dimensions, the rise of supermarkets, the growth of e-commerce and e-tailing and the start of the multichannel retailing slowly. The existing changing pattern of retailing in Bangladesh imitates with the different theories of the retail changes and finally matches with the combined retail changes theory. The nature of retail of the country belongs to the fourth wave of retail development. As the retail sector is very significant in terms of generation employment and its contribution to the GDP of the country, the government and other stakeholder of the industry should closely monitor the changes and trends in retail business to formulate the proper policy, guidelines and strategy to gain competitive advantage from the sector.

\section{References}

A2i. (2009). Digital Bangladesh Concept Note. Dhaka, Bangladesh: Government of Bangladesh. Retrieved from http://www.a2i.gov.bd/sites/default/files/resource docs/Digital\%20Bangladesh\%20Concept\%20Note Final .pdf

Ahmed S. M. Sohel (2017), Trends of Large Scale Retailing in Bangladesh, Anglisticum Journal (IJLLIS), ISSN: 1857--ISSN: $1857-8179$

Al Noor, M., \&Arif, R. B. (2011). Adoption of B2B e-commerce by the SMEs in Bangladesh. Innovative Systems Design and Engineering, 2(6), 48-59.

Alderson, W. (1957). Marketing behavior and executive action. Homewood, IL: Richard D. Irwin.

Ali M Yunus and FaroqueAnisur Rahman (2017), Diffusion of Supermarkets in Bangladesh: Miles to Go, Research Handbook of Marketing in Emerging Economies, Edward Elgar Publishing

Ali Md. Moktar, Ahmed Rafiuddin and Rahman Arifur (2013), Present Scenarios, Opportunities and Obstacles of E-Business In Bangladesh, D.U. Journal of Marketing, Vol. 16, No. 2, (Published in April, 2016)

Altenburg Tilman, KulkeElmar, MilagrosaAimée Hampel, Peterskovsky Lisa and Reeg Caroline (2016), "Making retail modernisation in developing countries inclusive A development policy perspective" "Innovative Approaches for Private Sector Development" of Deutsche GesellschaftfürInternationaleZusammenarbeit (GIZ) GmbH, German Federal Ministry for Economic Cooperation and Development (BMZ).

Arif Md. Zahir Uddin (2013), "A Study on Increasing Establishment of Superstores in Bangladesh with Special Reference to Dhaka City”, Anveshak, International Journal of Management (Aijm), Vol. 2 No. 1 ISSN: 2278-8913, Indira Institute of Management Thathawade, Pune, India.

Azad, S.N.M., Hossain, M.M. and Parveen, R. (2011). Customer Perception, Price and Demand Analysis. Journal of Business and Technology (Dhaka), VI (02), (July-December, 2011).

Babar Zahiruddin Md. (2017), Digital Divide: Concepts and Reality in Bangladesh, Journal of Business, 02(02), 24-33

Bachmann, D. (2008), 'Supermarkets on the Rise', The Daily Star, December 26, 2008. http://www.thedailystar.net/newDesign/news-details.php?nid=68728, accessed on July 28, 2011.

Bangladesh Bureau of Statistics-BBS (2013), Wholesale and Retail trade Survey,2009-2010,

Bangladesh Bureau of Statistics-BBS (2015), Bangladesh Economic Census-2013

Bangladesh

Bureau

of

StatisticsBBS.portal.gov.bd/sites/default/files/files/bbs.portal.gov.bd/page/057b0f3b_a9e8_4fde_b3a6_6daec38535 86/GDP_2018_19p_web\%20-02-04-2019.pdf

Bangladesh Super Market Owners Association-BSOA, Mohakhali, Dhaka.

Bangladesh Telecommunication Regulatory Council (2018), http://btrc.gov.bd/content/mobile-phonesubscribers-bangladesh-august-2018, accessed on September 20, 2018 at 08:05 p.m

Bank, T. W. (2015). Bangladesh development update. Bangladesh: The World Bank. Retrieved from http://documents.worldbank.org/curated/en/2015/04/24323972/bangladesh-development-update-april-2015

Bartels, R. (1981). Criteria for theory in retailing. In W. R. Stamptl\& C. E. Hirschman (Eds.), Theory in retailing: Traditional and nontraditional sources. Chicago, IL: American Marketing Association.

Blizzard, R. T. (1976). The competitive evolution of selected retail institutions in the United States and Australia: A culture ecological analysis. Unpublished doctoral dissertation, University of Colorado, Colorado.

Brown, S. (1987) "An Integrated Approach to Retail Change: The Multi-Polarization Model", The Service Industries Journal, 7(2), 1987, pp.153-164.

Brown, S. (1988) "The Wheel of the Wheel of Retailing", International Journal of Retailing, 3 (1), pp.16-37.

Clough, Roger (2002) Retail change: a consideration of the UK food retail industry, 1950-2010. PhD thesis, 
Middlesex University.

Dakora Edward A.N. (2012), Exploring the fourth wave of supermarket evolution: concepts of value and complexity in Africa, International Journal of Managing Value and Supply Chains (IJMVSC) Vol. 3, No. 3,

Datta Palto Ranjan (2017), Relationship Marketing and Customer Retention in Bangladesh's Food Retailing Sector, An unpublished Doctor of Philosophy (PhD) thesis submitted to the Department of Marketing \& Enterprise Business School University of Hertfordshire United Kingdom

Davidson, W.R. (1970) "Changes in Distributive Institutions", Journal of Marketing, January 1970, pp.7-10.

Davidson, W.R., Bates, A.D. and Bass, S.J. (1976) "The retail life cycle", Harvard Business Review, NovemberDecember 1976, pp.89-96.

Dreesmann, A. C. R. (1968). Patterns of evolution in retailing. Journal of Retailing, 44, 64-81

Farid et al (2018), Direct and Associated Factors Influencing the Growth in Supermarket Activity in Bangladesh, Asian Research Journal of Arts \& Social Sciences, 5(1): 1-12, Article no.ARJASS.38593, ISSN: 2456-4761

futurestartup.com/2018/05/09/inside-shwapnos-plan-to-build-a-hyperlocal-ecommerce business-with-saifulalam-and-ayaz-aziz/ on 9.9 .2018 at $11: 24$ p.m

futurestartup.com/2017/10/24/an-interview-sabbir-hasan-nasir-executive-director-acilogistics/futurestartup.com/2019/05/05/an-economic-case-for-reducing-vat-rate-on-supershops/

Garza, J. (2015, 9 January). Two silicon valley leaders join forces to launch and fund technology companies in Bangladesh. Retrieved 17 May, 2015, from http://fi.co/posts/12481

Gist, R.R. (1968) Retailing: Concepts and Decisions, New York, Wiley and Sons.

Guiltinan, P. (1974). Planned and evolutionary changes in distribution channels. Journal of Retailing, 50(2), 79$91,103$.

Hall, M., Knapp, J., \&Winsten, C. (1961). Distribution in Great Britain and North America: A study in structure and productivity. London, England: Oxford University Press.

Hollander, C. S. (1966). Notes on the retail accordion. Journal of Retailing. 42, 29-40.

Hossain Nasreen (2014), Socio-spatial Dialectic of Retail Environment in Developing Countries: Perception of Retail Trends in Dhaka, Asian Journal of Humanities of Social Sciences (AJHSS) Volume 2, Issue - 4, ISSN: $2320-9720$

Hossain Nasreen (2014b), History of Commercial Development in Dhaka and the Spatial Significance of Spontaneous Retail Growth IOSR Journal Of Humanities And Social Science (IOSR-JHSS) Volume 19, Issue 11, Ver. VII PP 66-73 e-ISSN: 2279-0837, p-ISSN: 2279-0845. www.iosrjournals.org

Hossain Nasrenn (1999), A Syntactic Approach to The Analysis Of Spatial Patterns In Spontaneous Retail Development In Dhaka, Space Syntax Second International Symposium, Brasilia

Humphrey, J. (2007). The supermarket revolution in developing countries: Tidal wave or tough competitive struggle? Journal of Economic Geography, 7, 433-450.

Islam Md. Shafiqul (2018), E-Commerce In Bangladesh: Growth And Challenges, IOSR Journal of Business and Management (IOSR-JBM), Volume 20, Issue 3. Ver. 5, PP 10-15e-ISSN: 2278-487X, p-ISSN: 2319-7668, www.iosrjournals.orgDOI: 10.9790/487X-2003051015

Islam Md. Shafiqul(2018), E-Commerce in Bangladesh: Growth and Challenges, IOSR Journal of Business and Management (IOSR-JBM) e-ISSN: 2278-487X, p-ISSN: 2319-7668. Volume 20, Issue 3. Ver. 5

ISLAM Mohammad Saifuland EVA Sharmin Akter (2019), Electronic Commerce toward Digital Bangladesh: Business Expansion Model Based on Value Chain in the Network Economy, Studies in Business and Economics no. 14(1), DOI 10.2478/sbe-2019-0007

Islam Muhammad Zahidul (2018), Growth of e-commerce driven by youth, The Daily Star, https://www.thedailystar.net/business/growth-e-commerce-driven-youth-144280

Islam Pial (2015), How 'e' is e-Commerce today? The Daily Star, https://www.thedailystar.net/how-e-is-ecommerce-today-43110

Izraeli, D. (1973). The three wheel of retailing: A theoretical note. European Journal of Marketing, 7(1), 70-74.

Jeffreys, J. B. (1954). Retail trading in Britain 1850-1950. Cambridge: Cambridge University Press.

Karim MdThohidul and Qi Xu (2018), E-commerce Development in Bangladesh, International Business Research; Vol. 11, No. 11; 2018 ISSN 1913-9004 E-ISSN 1913-9012, Canadian Center of Science and Education

Kaynak, E. (1979). A refined approach to the wheel of retailing. European Journal of Marketing, 13(7), 237-245.

Kim Sook-Hyun (2003), The Model for the Evolution of Retail Institution Types in South Korea, PhD thesis, Faculty of the Virginia Polytechnic Institute and State University

Kim Sook-Hyun (2006), The Model for the Evolution of Retail Institution Types in South Korea, Journal of Textile and Apparel, Technology and Management, Volume 5, Issue 1.

Kirby, D.A. (1976a) "The North American Convenience Store: Implications for Britain" ia Jones, P. and Oliphant, R. (eds.) Local Shops: Problems and Prospects, Reading, Unit for Local Planning Information, pp.95-101. 
Kirby, D.A. (1976b) "The Convenience Store Phenomenon: The rebirth of America's small shop", Retail \& Distribution Management, 4(3), pp.31-33.

KPMG. (2012). Bangladesh beckons: An emerging IT/ITeS outsourcing destination. Bangladesh: KPMG International. Retrieved from https:/www.kpmg.com/.../UNITC\%20KPMG\%20Whitepaper.pdf

Levy, M \&Weitz, B 2005, Retailing Management, 6th Edition, McGraw-Hill, New York

McCammon, B.C Jr. (1975) "Future Shock and the Practice of Management" in Levine, P. (ed.) Attitude Research Bridges the Atlantic, Proceedings Series 16, Chicago, American Marketing Association, pp.71-89.

McNair, P. M. (1958). Significant trends and developments in the post war periods. In A. B. Smith (Ed.), Competitive distribution in a free high level economy and its implications for the university. Pittsburg: University of Pittsburg Press.

New Age (2017), Bangladesh e-commerce sector to grow to Tk 900cr this year: report, http://www.newagebd.net/print/article/28655

NewAge (2018), Cabinet approves e-commerce policy, http://www.newagebd.net/article/46193/cabinetapproves-e-commerce-policy

Nsimbi et al. (2015), Modern Retailing and its Implications for Developing Countries: Insight for Retail Managers, Business Management and Strategy ISSN 2157-6068, Vol. 6, No. 1, Macro thinks Institute

Nyenrode. (2014). ICT sector study Bangladesh: Bridging the gap between Dutch and Bangladeshi ICT sectors. Breukele, Netherlands: Nyenrode Business Universiteit. Retrieved from http://www.basis.org.bd/resource/ICT\%20Sector\%20Study\%20Bangladesh.pdf

Oishe Sanjida Farhana (2017), Customers' Behavior towards E-Commerce in Bangladesh: An Empirical Study On Some Selectedb2c E-Commerce Sites, International Journal Of Business And Management Vol. V, No. 1, Doi: 10.20472/Bm.2017.5.1.003

Oren, C. (1989). The dialectic of the retail evolution. Journal of Direct Marketing, 3(1). 15-29.

Rahman Md. Mustafizur, Islam Shahidul and Hasan Mohammad Tanvir (2016), A Redevelopment Approach to a Historical Market in Sylhet City of Bangladesh, Civil Engineering and Architecture 4(3): 127-138, 2016 http://www.hrpub.org DOI: 10.13189/cea.2016.040305

Rahman Mohammad Toufiqur (2016), Customers' Attitude towards Online Shopping: The Case of Bangladesh, World Journal of Social Sciences, Vol. 6. No. 2, Pp. $82-91$

Rahman Syed Mahmudur (2015), Optimizing Digital Marketing for Generation Y: An Investigation of Developing Online Market in Bangladesh, International Business Research; Vol. 8, No. 8; 2015 ISSN 1913-9004 E-ISSN 1913-9012, Canadian Center of Science and Education

Reardon Thomas et al (2003), "The Rise of Supermarkets in Africa, Asia, and Latin America" American Journal of Agricultural Economics

Reardon, T. (2008), Supermarkets and their Role in Emerging Markets, SA-AARES Conference Presentation. Accessed http://www.aares.org.au/Images/AARES\%20Documents/Supermarkets_and their_role\%20(Part\%201).p df

Reardon, T., Henson, S. and Berdegue, J. (2007), "'Proactive fast-tracking' diffusion of supermarkets in developing countries: implications for market institutions and trade", Journal of Economic Geography, Vol. 7 No. 4, pp. 399-431.

Reardon, T., Timmer, C. P., Barrett, C. B. and Berdegue', J. A. (2003), "The rise of supermarkets in Africa, Asia and Latin America", American Journal of Agricultural Economics, Vol. 85 No. 5, pp. 1140- 1146.

Reardon, T., Timmer, C. P., Barrett, C. B. and Berdegue', J. A. (2003), "The rise of supermarkets in Africa, Asia and Latin America", American Journal of Agricultural Economics, Vol. 85 No. 5, pp. 1140- 1146

Reardon, T.\& Gulati, A.(2008). The Supermarket Revolution in Developing Countries: Policies for Competiveness with Inclusiveness, IFPRI Policy Brief 2, Washington

Regan, W. J. (1964). The stages of retail development. In R. Cox, W. Alderson \& S. J. Shapiro (Eds.), Theory in marketing. Homewood, IL: Richard D. Irwin.

Robenhagen, S., Shahrukh, S. A., \&Taufiq, S. (2014). ICT and e-commerce booming in Bangladesh. Bangladesh: Embassy of Denmark $\quad$ Retrieved from http://bangladesh.um.dk/en/ /media/Bangladesh/Documents/Teaser\%20on\%20e-commerce\%20final.pdf

Sahel Samira, Anwar Tasmia and Nandi Barnali(2018), Factors Affecting the Selection of an E-Commerce Website in Bangladesh: E-tailers' Perspective, International Review of Management and Marketing 8(4), 16.ISSN: 2146-4405

Sarker Md. Atiqur Rahman and Ashrafi Dewan Mehrab (2018), "The relationship between internal marketing and employee job satisfaction: A study from retail shops in Bangladesh", Journal of Business and Retail Management Research (JBRMR), Vol. 12 Issue 3, Academy of Business and Retail Management (ABRM)

Shahid Rokeya Binte (2017), Building Strong Brand Equity of Supermarkets in The Context of Bangladesh, International Journal of Economics, Commerce and Management, United Kingdom Vol. V, Issue 6, http://ijecm.co.uk/ISSN 23480386 
Shamsher, R. \& Hossain, M. J. (2011). Effect of store and product attributes influencing store loyalty: the Bangladesh retail context. The Dhaka University Journal of Business studies. 32(2). p. 157-170.

Shamsher, R. \& Hossain, M. J. (2012). Consumer behavior in retailing: A comparative study between traditional and large-scale retailing. The Chittagong University Journal of Business studies.21. p. 179-197.

Shamsher, R., Abdullah, N. and Saha, S.(2012). The Changing Trend of Consumer Food and Cosmetics: The Bangladesh Retail Context. The Journal of Comilla University. 1(1), 183-194.

Shamsher Robaka (2014), CONSUMER SHOPPING PREFERENCE TOWARDS ORGANIZED RETAILING IN BANGLADESH, ESOFT Metro Campus International Journal, 2(1), Volume 1, Issue 1,pp 155-179

Shamsher Robaka (2017), Role of Store Image Influencing Store Loyalty: A Study of The Retail Industry in Bangladesh, An Unpublished thesis of Doctor of Philosophy in Marketing, Faculty of Business Studies, University of Dhaka.

Shaw, G. (1978). Processes and patterns in the geography of retail change. Geography, 24.

Siddiqui N, Ahmed JU, Hasan M (2006), 'New Generation of Retail Management in Bangladesh - Customer Satisfaction through Value System Management', SEU Journal of Business Studies, vol. 2, no.2, pp. 1-18.

Tschirley, D., Ayieko, M., Hichaambwa, M., Goeb, J.,\& Loescher (2010). Modernizing Africa's fresh produce Supply Chains without Rapid Supermarket Takeover: Towards a Definition of Research and Investment Priorities, MSU International Development Working Paper No.6, Department of Agricultural, Food and Resource Economics, Michigan State University

The Daily Star (2018), E-commerce sites basking in Eid, World Cup orders, https://www.thedailystar.net/business/e-commerce-sites-basking-eid-world-cup-orders-1586485

World Bank. (2014). Implementation Status \& Results - Bangladesh: Leveraging ICT Growth, Employment and Governance Project (P122201). (ISR16728). The World Bank Retrieved from http://www.worldbank.org/projects/P122201/leveraging-ict-governance-growth-employmentproject?lang=en

Wrigley, N. and Lowe, M. (2010), The globalization of trade in retail services, report commissioned by the OECD Trade Policy Linkages and Services Division for the OECD Experts Meeting on Distribution Services, Paris, 17 November 2010, retrieved from http://www.oecd.org/tad/services-trade/46329746. pdf 